\title{
BEAUTY AND MYSTERY OF GANDHARA ART
}

\author{
Shahid Ahmad Rajput \\ Professor in Architecture and Design, $\backslash$ \\ COMSATS Institute of Science and Technology (CIIT), Pakistan \\ sarajput@icloud.com
}

\begin{abstract}
This paper is a short history to establish the location, era and the main actors involved in the creation of a civilization what is generally known as Gandhara. It also includes a brief history of the Art and Architecture of Gandhara as the main feature and the beauty and mystery associated therein. Limitation of the length of paper will keep our discussion on three main centers as below. Necessary visual evidence is also included to justify the Beauty and the Mystery attached to the art of Gandhara for which this paper is initiated. Fact of the matter is that hundreds of books are written on Gandhara Civilization but this point "Beauty and Mystery of Gandhara" has hardly been addressed. This paper is therefore an attempt to fill the gap long felt by the author and last but not the least this paper is dedicated to the love and affection to the artwork of the monks who produced the Master Pieces of Gandhara, both in Stone and Stucco. The analysis is made according to the existing literature and author's own experience and interpretation.
\end{abstract}

Keywords: Gandhara, Taxila, Charsadda, Swat, Butkara, Chakdara, Takshasila, Takht-iBahi, Pushkalavati, Charsadda, Chakdara and Stucco.

\section{Introduction}

Among the heritage of Pakistan there are hundreds if not thousands of archaeological and historical sites and monuments representative of the bygone days starting from pre-historic period to the present day. The history goes as far back as the human information goes (All sources: Ihsan Nadeim, 2006; Hussain, J. 1983; Raza, M. Hanif, 2003; Rajput, AB.1963; Rajput, SA. 2009). This includes the archaeological sites of Indus Valley Civilizations such as Mohenjo-Daro in Sindh, Harappa in Punjab and Mehrgarh in Baluchistan. The Indus 
Valley Civilization was followed by the 'Gandhara Civilization', which is the main focus of this paper.

Stated by Abdur Rasool (2006:89) the land of Pakistan witnessed the origin and growth of the Gandhara Civilization, which starts shortly after the arrival of Alexander the great in $325 \mathrm{BC}$. Also this was here that Alexander the great was defeated for the first time in his life by Raja Porus of Jhelum. Alexander's hold over the Indus Valley was therefore brief and short lived.

According to V. Smith (1907: 117-18)two years later after the death of Alexander in 323 BC, his empire was shattered to pieces and the princes of India had leisure to assert independence within their principalities. In the meantime Chandra Gupta Maurya, a scion of the royal family of Magadha, occupied a greater portion of North West India. In the course of next few years, he was able to overthrow the Nanda regime from Magadha to make himself the master of Hindustan.

Chandra Gupta reigned for 25 years and abdicated the throne in favour of his son Bindusara in 298 BC. Like his great father, he established diplomatic relations with the Greek rulers of west, especially those belonging to the house of Seleucus because his daughter was given in marriage to Chandra Gupta in a deal after the Greeks were defeated in one of their battles with Chandra Gupta Maurya. His contemporary Antiochus Soter likewise manifested the same eagerness by the exchange of gifts. Abdur Rasool (2006:89-95)

Asoka who took up the reins of government in $272 \mathrm{BC}$ was undoubtedly the ablest and most enlightened sovereign of ancient India. In 261 BC he marched on Kalinga, modern Orissa with the most northerly portion of Madras. The fierce battle between the contending armies resulted in a heavy carnage, which frustrated all designs of further conquest. The tragic scene of the battle had a tremendous effect on the mind and intellect of the warrior king who then resolved to abandon the traditional course of waging war and turned to the teachings of Lord Buddha. Buddhism was then declared as the State religion of India and was enforced on the reluctant masses by the decree of the King. A true and ardent champion of the Buddhist faith, Asoka molded his life according to its sublime doctrine, which he got engraved on rocks, pillars and plates still existent in Shahbaz Garhi, Naushehra and Mansehrah in the province of Khyber Pakhtun Khwah (KPK) and some other parts of India. The death of this 
great religious monarch proved a decisive blow to the United Indian hegemony and brought about the ultimate fall of Mauryan Empire. The control of the Indus Valley then shifted to the Greek rulers of Bactria but their hold over the country was too uncertain and precarious. V. Smith (Vol-2: 166-70); Ghafur, (1988: 94-101).

About the middle of 2 nd century AD a new power rose to eminence in Central Asia; they were the Yuch-chi, a people of nomadic and barbaric tendencies. V. Smith, (Vol. 2: 248). They soon plunged westward and put an end to the Greek Kingdom of Bactria, which existed in that region since the conquest of Alexander the Great. An offshoot of that tribe called Scythians, advanced to the Afghan hills and having crossed the Hindukush they spread over a great portion of the Punjab like whirlwind. Aitkin, E.H, (1907:87)

The first sovereign of the race claiming sovereignty over Punjab was Kadfices I, who reigned for 30 years (15-45 AD) V. Smith, (Vol. 2:259). Sindh at this juncture was under the domination of Indo-Parthian Greek kings, ruling the realm since the downfall of the Mauryas. The conquest of Lower Indus Valley was however, reserved for a later period when Kanishka, the third ruler of this house, made the final subjugation of the country. Kanishka is also famous for having convened a Buddhist council, third of the series after his great predecessor Asoka and like those of Asoka, the commentaries composed by his Council have still the force of religious canon in China, Tibet and Mongolia.V. Smith, (Vol. 2:267; Aitkin, 1907: 8). Kanishka died in 123 AD after a benevolent rule of nearly 45 years and was followed by three successors Vasishka, Huvishka and Vasudeva.

By the middle of the fifth century AD, another savage race, the white Huns, began to pour into India. Issuing from their wild reservoirs in Central Asia, they advanced to the Hindukush and, having entered Punjab, they appeared on the very banks of Ganges with astonishing speed. They were, however, defeated by Sikandar Gupta, with great slaughter and were forced to retreat. Taking no cognizance of the disaster inflicted on them, they appeared again with characteristic freshness and vigor. But this time they did not venture to advance the interior and contended themselves with retaining the sovereignty over Punjab and Kashmir. Havell, (1918:173-74). It is due to the White Huns that the Gandhara civilization was put to and end. (all Sources given below). 
Heuen-Tsang, the Chinese pilgrim who visited the Indus Valley in the first half of the sixth century AD speaks of these kings as Sudras. The reference is perhaps to Rai Seharas I. He reports the general prosperity of the country under that rule. V. Smith, (Vol. 2: 354-55). The other rulers of the dynasty were Rai Sehasi I, Rai Seharas II, and Rai Sehasi II. The rulers of this dynasty were all Buddhists and reigned over the country with great prudence and justice.

With this background of history in view one must be mindful of the development of a Culture in the North and Northwest of India, which was named by the historian and archaeologists as Gandhara Culture. The area covered by the Gandhara Civilization is shown in the map (Figure-I) that includes the present day Pakistan, Northeast of Afghanistan and Southwest of China. We shall confine this paper to the limits of Pakistan housing the real treasures of the Gandhara Civilization. The main centers of Gandhara in Pakistan are Swat, Pushkalavati (present day Charsadda in the KPK) and Takshasila (present day Taxila in the Punjab) as under:

\section{Important Archaeological Sites of Gandhara}

Some of the world's richest heritage sitesin modern day northern Pakistan, 'Gandhara Civilization' is considered to be the zenith of civilizations of the bygone days. Swat, Pushkalavati and Takshasila were the prime cities of Gandhara Civilization. Pushkalavati remained the capital of Gandhara from 6th century BC to the 2nd century AD. Takshasila remained the important center of trade and learning from 2 nd century $\mathrm{BC}$ to the 5 th century $\mathrm{AD}$ when the White Huns put an end to Gandhara. Buddhist Kushan kings are the most notables of the rulers in Gandhara civilization. (Rajput, 2009:30-35).

\section{Taxila}

The World Heritage site of Taxila is located in Punjab Province, about 35 kilometers from Islamabad (the Capital of Pakistan). Taxila is an archaeological paradise and includes numerous related buildings, fortified settlements, stupas and monasteries, and shows foreign influences in its art and architecture. It acted and played an important role as a Buddhist training center between the 2 nd century BC and the 5th century AD. At Taxila one can see the great Dharamrajika Stupa said to have contained the original relics of Buddha. There are many images of Buddha, in stone and stucco and numerous panels depicting all the important 
stages of the great Sage's life (Figure-II, III and IV. a\&b). Each bit of carved sculpture shows extravagant beauty and mesmerizing artistry (Figure V and VI. a\&b); from colossal to miniature there are literally thousands of such masterpieces in this collection. Taxila is important in many ways such as its an ancient city of northwestern Pakistan, its one of the most famous archaeological sites in the world, its the ancient capital of the western Punjab. Taxila, the ancient Takshasila "City of Stones cutters" was once a flourishing city along the trade routes of central Asia and China. The age-old tradition of stone cutting still continues in the form of making the devices for grinding the spices ${ }^{\mathrm{i}}$.

Taxila is described in some detail in later Jataka tales, written in Sri Lanka around the 5th century AD. Taxila is considered a place of religious and historical sanctity by Hindus and Buddhists alike. Whether or not one considers it a university there are many Stupas in Taxila including the famous Stupa of Dharmarajika with attached monastery where the monks were trained and taught the philosophy of Buddhism ${ }^{\text {ii }}$. Having acquired a certain level in the Buddhist Philosophy these monks were then sent to China and through China to Japan and other eastern countries. Taxila played an important role as a major center for trade and learning during the hay days of Buddhism from $2^{\text {nd }}$ century BC to the $5^{\text {th }}$ Century AD ${ }^{\text {iii }}$.

\section{Buddhist Heritage of Swat}

Although it is generally accepted that Tantric Buddhism first developed in the country of Uddiyana under King Indrabhuti, there is an old and well-known scholarly dispute as to whether Uddiyana was in the Swat valley, Orissa or some other place, (flourished in eighth century AD). Ancient Gandhara, the valley of Pekhawar, with the adjacent hilly regions of Swat and Buner, Dir and Bajaur was one of the earliest centers of Buddhist religion and culture following the reign of the Mauryan emperor Asoka, in the third century BC. The name Gandhara first occurs in the Rig-Veda, which is usually identified with Swat, which was a popular destination for Buddhist pilgrims. Buddhist tradition holds the Buddha himself came to Swat during his incarnation as Gautama Buddha and preached the people. It is said that the Swat valley was filled with fourteen hundred imposing and beautiful Stupas and monasteries, which housed as many as 6,000 gold images of the Buddhist pantheon for worship and education. Archaeologists now know of more than 400 Buddhist sites covering 
an area of 160 sq.km in Swat valley alone. Among the important excavations of Buddhist sites in Swat one is Butkara containing original relics of the Buddha. Butkara is one of the most important sites of Gandhara in Swat. The Butkara Stupa is an important Buddhist Stupa and is said to have been built by the Emperor Asoka, but it is generally dated slightly later to the 2nd century BC. The Stupa was enlarged on five occasions during the following centuries, every time by building over, and encapsulating, the previous structure.

\section{Chakdara}

Another important site in Swat is called Chakdara. It has been an important center for the last 3500 years and is littered with remains of the Gandhara grave culture, Buddhist sites, and Hindu Shahi forts. The ancient route from Afghanistan via Nawa Pass and Katgala Pass crosses the Swat River at Chakdara. Buddhist sculpture of the $1^{\text {st }}$ to $7^{\text {th }}$ centuries from nearby sites and Hindu Shahi artifacts are now displayed at Chakdara Museum. The most important site in Chakdara is Damkot Hill. The top of Damkot Hill has been excavated and pottery and jewelry have been discovered. These items are now displayed in the Saidu Sharif Museum. Ahmad Hassan Dani excavated a Buddhist stupa and monastery of the first century AD in 1962-65. There are some Buddhist carvings at the foot of the hill. Ghafoor, (1988: 94-101).

\section{Charsadda}

It was once the Capital of the Kingdom of Gandhara, however around 516 BC Gandhara became part of the seventh satrapy or province of the Achaemenid Empire and paid tribute to Darius the Great of Persia, until its overthrow by Alexander the Great in the 4th century BC. After the death of Alexander in 323 BC the Indian Emperor Chandragupta Maurya rose to power and brought Gandhara under his sway. According to a popular tradition, Emperor Asoka built one of his Stupas there. This Stupa was mentioned by the famous Chinese Buddhist pilgrim Hieun Tsang who visited the area in 630 AD. According to him Po-Lu-Shc (as he called the Stupa) was $2 \frac{1}{2}$ miles in circumference where Buddah preached Law.

\section{Takht Bahi}

It is a Buddhist monastic complex dating to the 1st century BC. The complex is regarded by archaeologists as being particularly representative of the architecture of Buddhist monastic 
centers of that era. It was listed as a UNESCO World Heritage Site in 1980 (Figure VIII). Takht means "throne" and Bahi, "water" or "spring" in Urdu. The monastic complex was called Takht-i-Bahi because it was built atop of a hill watered by a spring. There are four main areas of the Takht Bahi complex:

i. The "Stupa Court", a cluster of Stupas located in a central courtyard.

ii. The monastic chambers, consisting of individual cells arranged around courtyard, assembly halls, and a dining area.

iii. A temple complex, consisting of Stupas, similar to the Stupa Court, but of later construction.

iv. The Tantric monastic complex, which consists of small, narrow cells with low openings, in the basement, which may have been used for certain forms of Tantric meditation.

The monastic complex was founded in the early 1 st Century AD. Despite numerous invasions into the area, Takht-i-Bahi's hilltop location seems to have protected it from destruction, unlike many comparable early Buddhist monastic complexes. The complex was occupied continuously until the modern era, when charitable funding for the site ended. There are so many Archaeological Sites still remaining in Pakistan as well as in the neighboring country Afghanistan such as Bamyan and Hadda. However, for sake of limitations we shall contain ourselves to few sites in Pakistan only and now come to the main point of the beauty and mystery of the Gandhara.

\section{Beauty and Mystery of Gandhara Art and Architecture}

The Gandhara art and architecture represents one of the finest arts not only in Pakistan but also in the entire world. This art principally revolves around the religion and in terms of architecture it represents a unique type of architectural complex (Stupa and Monastery), (Figure VII. A\&b. and VIII), that continues to prevail in the present day Pakistan ${ }^{\text {iv }}$. As a matter of fact the religion of this county changed from Buddhism to Islam during the early eleventh century (Rajput, 2009: 30-50; Zabeeh, 1984:109-110; Zabeeh, 1995:70-80) with the arrival of the Muhmud of Ghazni but the pre-existing culture still continues ${ }^{\mathrm{v}}$. According to Dani religion has always played a pivotal role in the society of India. To our interest Gandhara Culture developed in the northern India with the Buddhist religion as the main driving force. This culture started showing its distinct identity with the Royal patronage 
during the second century BC when Asoka the Great adopted Buddhism for himself first and then declared it as the state religion. (Hill, John E. 2003:90-95; Ghafur, 1988: 34-35 et. al).

After Asoka, the Bactrian Greeks occupied this land for almost a century during which time nearly forty Kings and Queens of Greek origin ruled this land of Gandhara. The impact of religion i.e. Buddhism remained predominant throughout this period of Greek occupation. Bhir mound was abandoned in Taxila and the Greeks established new planned cities such as Sirkap and Sirsukh. The Greeks also adopted Buddhism to strengthen their rule in the Gandhara area. With this the foreign influence of Greek art made its way into the local art thus the local art acquired a new dimension, which surpassed the beauty of Hindu and Greek sculpture as well as the Greek Art and architecture. (Hussain, J. 1983:140; Ghafur, 1988:34; Ihsan Nadiem, 2006: 35-40 et. al).

Then again as mentioned elsewhere, during the second century AD Kanishka the great, like his predecessor Asoka, also patronized the Buddhism and hundreds of Stupas and monasteries were sponsored by the state. It was under his able leadership and generous patronage that the Gandhara art flourished to its full bloom. The life of Buddha was not only translated in stone but another medium stucco was also introduced. Stucco sculptures of gigantic sizes were created and placed in and around the Monasteries and Stupas all over. The art collectors looted most of the large sculptures in stucco during the British period and others were destroyed with natural forces. Nevertheless, still we have many stucco sculptures around the walls of the Stupas and inside the monasteries at Taxila Charsadda and Swat. Most of the sculptures both in stone as well as in stucco are shifted to the site museums.

Today Gandhara sculptures are not only found in the National and site museums of Pakistan but also occupy prominent position in the museums and art galleries of Far East, Australia, Europe and America. Musee Guimet of Paris, Berlin Museum of Germany, V\&A and BM of London and Metropolitan Museum NY and the Oriental Chicago, USA are few example of the international museums which house the best Gandhara sculpture. This international interest is more than sufficient evidence for the authentic beauty of the Gandhara sculpture just as the Greek pottery and Egyptian art are known in the world so is Gandhara and will continue to amaze the art enthusiasts for years to come. 
The mystery of the Gandharain the opinion of this author is that despite the fact that each and every piece of art i.e. architecture, sculpture or jewelry either in stone, stucco or metal is exquisite, rather the master piece and some of the sculptures have such a serene smile on their faces that surpasses any known smiles including that of Mona Liza's smile, yet none of this sculpture has any signature on them (Figure V and VI a \& b). Comparing with today's trend every artist of Gandhara must have earned the Nobel Prize several times in his lifetime but they remained unknown and the history is also silent. The history has it that man has either worked with fear or with love.

In case of Gandhara, the latter seems to be the case. The people of Gandhara loved their religion so much so that they devoted their lives in learning, propagating and serving it as much as their lives could allow them. Thus they created the sculptures of Buddha (Figure IVI) and erected the huge Stupas and monasteries (Figure VII-VIII) across the length and width of Gandhara and they took their task as an act of worship upon themselves. This devotion and selflessness towards serving the religion as an act of worship by the artists of Gandhara is the key to understand the mystery and beauty of Gandhara art, which still amazes the visitors ${ }^{\mathrm{vi}}$.

Notes

\footnotetext{
i . The author lives in Taxila, confirms that all the mortar \& pestles for grinding the spices are made and supplied to rest of the country from here.

ii. The author belongs to the valley and knows all the archaeological sites well and as an archaeologist he can deduce the purpose of various structures of the ruined buildings as to what role these building might have played during the time when they were the living buildings.

iii . As cited by Prof. Dani and all other sources that two main branches of Buddhism Originate from Taxila Mahayana and Hinayana. While Mahayana traveled towards the North to China and beyond, the Hinayana traveled to the South towards India and Sri-Lanka.

iv . Bussagli Mario. 1973. Oriental Architecture, New York. I must add here that Bussgali has produced a voluminous work on the oriental architecture and has included a chapter No.1 on the Indus architecture but its so strange that he did not include the Gandhara architecture, which is such as beauty.

v . The author has worked with Prof. Dani, who is considered an authority on the Archaeology and Culture of Gandhara. It was from him that the author learnt as to how the continuity of culture is found in present day Pakistan. The author is grateful to late Dani for giving the insight.

vi . This is the synthesis of all sources and discussions with experts and personal understanding that the author has developed over the year on the Gandhara art. Any comment shall be appreciated.
}

Researcher (Vol. 3, No. 3, January 2018) 


\section{References}

Abdur Rasool. 2006. Tarikh-i-Insani. (Urdu) University of Sargodha, Pakistan.

Aitken E.H. 1907. Gazetteer of the province of Sind.

Bussagli Mario. 1973. Oriental Architecture. New York

Ghafur Agha. 1988. Taxila ka taehzzeebi safarnama. (urdu) Rawalpindi.

Havell E.B. 1918. History of Aryan Rule in India. NY.

Hill, John E. 2003. "Annotated Translation of the Chapter on the Western Regions according to the Hou Hanshu". 2nd Edition.

Hussain J. 1983. An Illustrated History of Pakistan. Oxford University Press, Karachi

Ihsan Nadeim. 2006. Taxila Valley and beyond history and monuments. Islamabad: Pothohar

Rajput. A.B. 1963. Architecture in Pakistan. Pakistan Publications P.O. Box. No 183.

Rajput. S.A. 2009. History of Islamic Art based on al-Mansurah evidence. Lahore

Raza, M. Hanif. 2003. Islamabad and Environs. 3rd ed. Islamabad: Best Books.

Vincent Smith. 1907. History of India: From Sixth century B.C to Mohammedan Conquest (Vol.2). London, Grolier Society.

Zabeeh, Mohammad Ismail. 1984. Islämabād: Tärikh, Ta'mīr, Aur Shimatī 'ilāqe = Islamabad: History, Construction, and Northern Areas of Paskitan, Karach., 1984

Zabeeh, Mohammad Ismail. 1995. Islämabād, Manzil-i Murad: Mā̄īi, Hă, Mustaqbil. Islāmābād: al-Qalam.

\section{Figures}

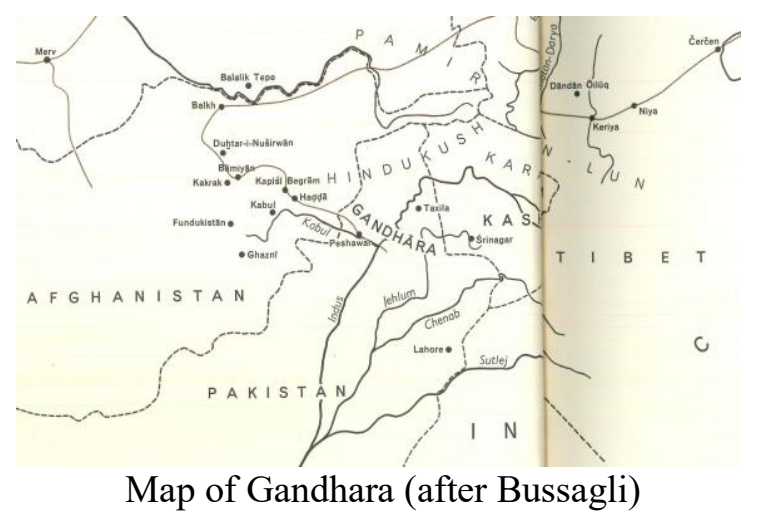

Researcher (Vol. 3, No. 3, January 2018) 


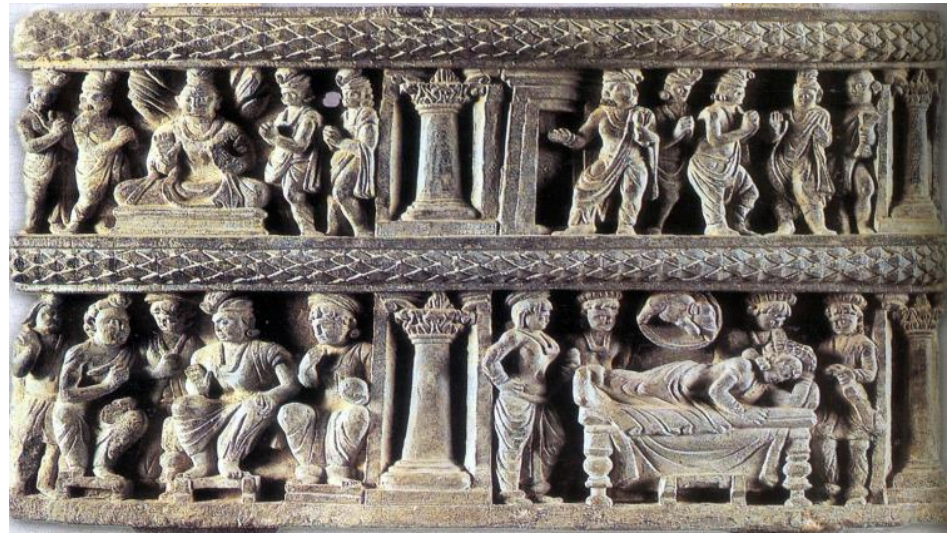

Figure II: Stone sculpture depicting Dream of Queen Maya \& its interpretation, Swat Museum

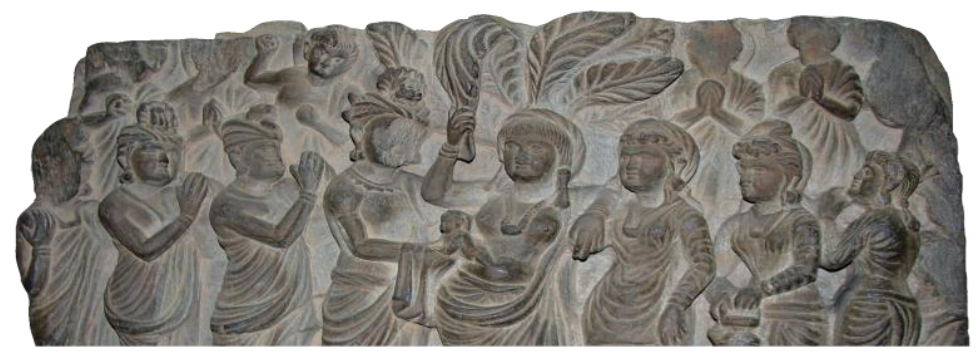

Stone sculpture depicting Birth of Siddhartha, Peshawar Museum

a
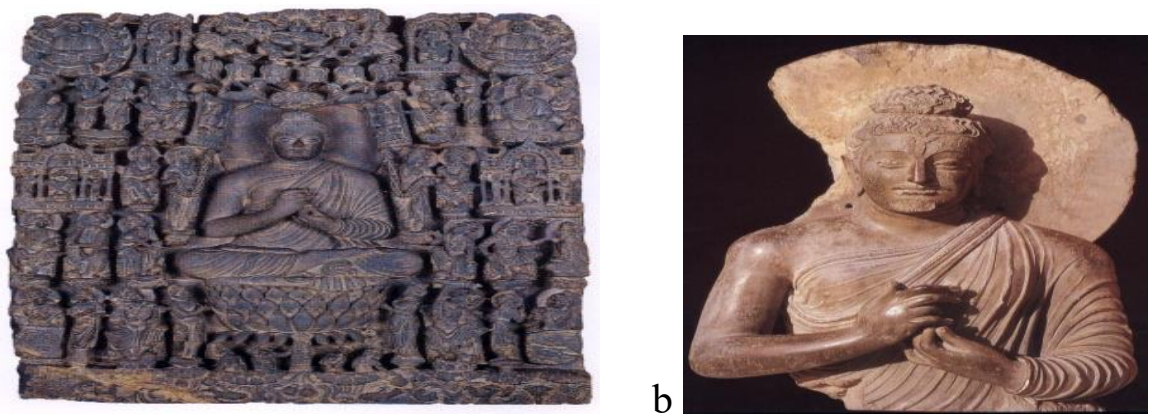

a). Preaching Buddha, in Stone, Peshawar. b). Preaching Buddha, in Stone, Taxila

Researcher (Vol. 3, No. 3, January 2018) 
a). Buddha's head in Stucco.

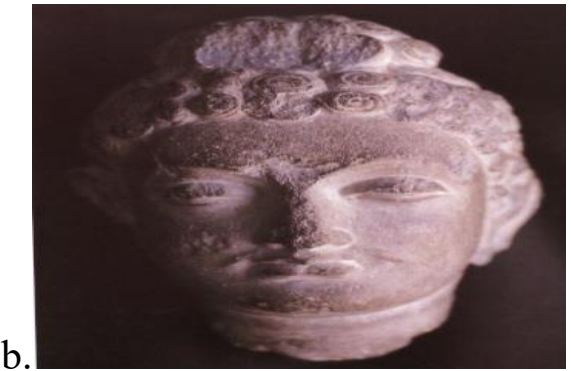

b). Buddha's head in Stone a.

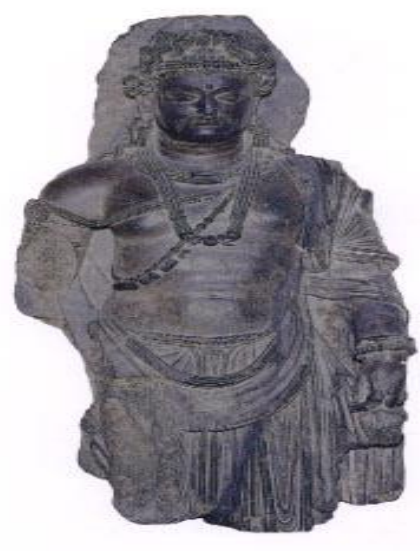

a). Stone sculpture of the Prince

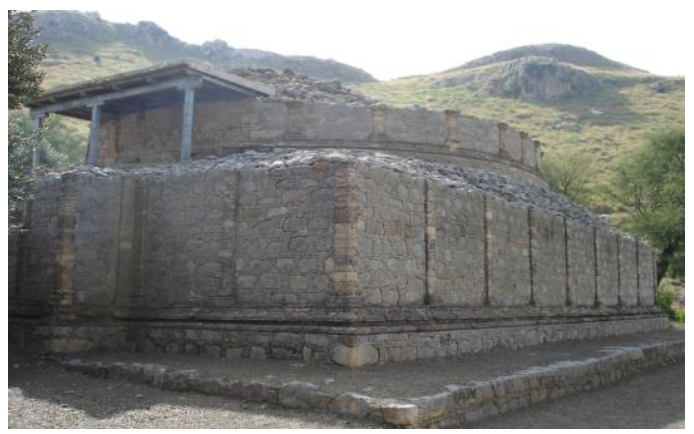

a. Stupa at MohraMoradu. b.

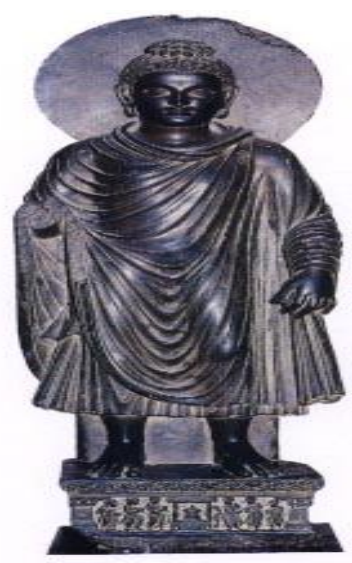

b). Stone sculpture of Bodhisatva

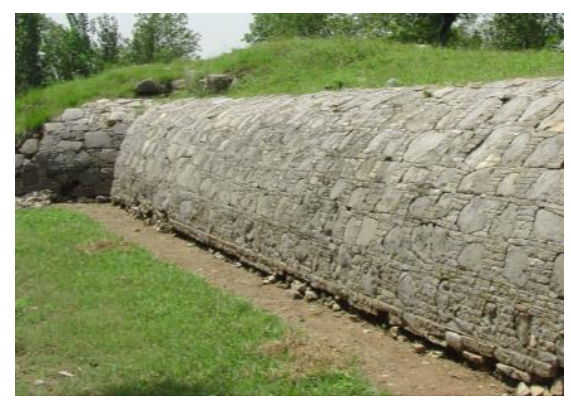

b. Original Boundary wall at Taxila 